\title{
Influence of Seawater on the Carbon Steel Initial Corrosion Behavior
}

\author{
Yuwei Liu ${ }^{1,2^{*}}$, Zhenyao Wang ${ }^{1 *}$, Yinghua Wei ${ }^{1}$ \\ ${ }^{1}$ Institute of Metal Research, Chinese Academy of Sciences, Wencui Rd 62, Shenyang, 110016, PR \\ China \\ ${ }^{2}$ School of Materials Science and Engineering, University of Science and Technology of China, \\ Wencui Rd 62, Shenyang, 110016, PR China \\ *E-mail: ywliu12s@imr.ac.cn, zhywang@imr.ac.cn
}

doi: $10.20964 / 2019.02 .36$

Received: 3 August 2018 / Accepted: 12 November 2018 / Published: 5 January 2019

In this study, the influence of seawater on the carbon steel initial corrosion behavior, exposed to the high temperature, high humidity, and high salt marine atmosphere of the south sea, is investigated using the weight loss measurement, a stereomicroscope, a laser scanning confocal microscope (LSCM), a scanning electron microscope (SEM), X-ray diffraction (XRD), infrared spectroscopy (IRS), potentiodynamic polarization, and in-situ electrochemical impedance spectroscopy (EIS). According to the results, the kinetics of corrosion process is an accelerating process following the empirical equation $D=A t^{\mathrm{n}}$. The composition of the rust layer was mainly consisted of $\beta-\mathrm{FeOOH}, \gamma-\mathrm{FeOOH}, \delta-\mathrm{FeOOH}, \alpha-$ $\mathrm{FeOOH}$, and $\mathrm{Fe}_{3} \mathrm{O}_{4}$ for all corrosion periods. The existence of many voids and microcracks in rust layer and the variation of surface roughness resulted in the rust without protective effect. With the increase in the corrosion time, the charge transfer resistance decreased, whereas the corrosion current density and the corrosion rate increased gradually.

Keywords: Carbon steel; Seawater; LSCM; In-situ EIS

\section{FULL TEXT}

(C) 2019 The Authors. Published by ESG (www.electrochemsci.org). This article is an open access article distributed under the terms and conditions of the Creative Commons Attribution license (http://creativecommons.org/licenses/by/4.0/). 